\title{
Import Functions for Pakistan - A Simultaneous Equation Approach
}

\section{Mohammad Afzal}

\section{Introduction $^{1}$}

It is highly desirable that the behaviour of imports is studied in both demand and supply scenarios. Many studies in international trade have estimated the price elasticities of demand but very few studies have been used to study supply behaviour in international trade. However, Khan (1974), Haynes and Stone (1983 a) and Arize (1986), using Simultaneous Equations estimation have reported estimates of import supply in international trade. To study the true behaviour of imports, the choice of the functional form is important. Different researchers have used different forms according to their objectives and inclinations. Leamer and Stern [(1970), pp.8-19] have discussed at length the functional form of the import demand but they have not said anything about import supply. Leamer and Stern (1970) noted that the linear and log-linear forms of the import demand are:

$$
\begin{aligned}
& \mathrm{M}=\mathrm{a}+\mathrm{b} \mathrm{Y} / \mathrm{Py}+\mathrm{c} \mathrm{Pm} / \mathrm{Py}+\mu \\
& \log \mathrm{M}=\log \mathrm{a}+\mathrm{b} 1 \log (\mathrm{Y} / \mathrm{Py})+\mathrm{c} \log (\mathrm{Pm} / \mathrm{Py})+\log \mu
\end{aligned}
$$

Where

$$
\begin{aligned}
& a=\text { constant term in the regression } \\
& b=\text { Marginal propensity to import } \\
& c=\text { import coefficient of relative prices } \\
& \mu=\text { Error term reflecting other minor influences }
\end{aligned}
$$

In the linear form, income and price elasticities of the import demand will depend upon the level of these variables, while in the log-linear form $b_{1}$ and $c_{1}$ are income and price elasticities. There are no clear-cut criteria for choosing a functional form. The choice depends on the preferences and objectives of the researcher. The limitation of the linearform is that price elasticity will diminish as income grows. Under such

\footnotetext{
* Department of Economics, Gomal University, D.I. Khan - Pakistan.

${ }^{1}$ This is part of the author's Ph.D. Thesis submitted to Bahauddin Zakariya University, Multan (Pakistan).
} 
circumstances, the log-linear form might be preferred. Both forms assume that the basic demand relationship is linear. The use of linear or log-linear form may be looked at as testing the significance of a particular functional form rather than the significance of the particular explanatory variables.

Khan and Ross (1977) have demonstrated that log-linear specification was better than a linear one for import demand for three major industrial countries [USA, Japan and Canada]. Sarmad (1989) has reported that based on the experience of a vast number of countries the log-linear form is the preferred choice for the aggregate import demand equation.

The PIDE Macro-econometric model of Pakistan's Economy [Naqvi et al (1983)] has specified 13 equations for the foreign trade sector. There are three categories, each of exports and imports. Import equations are demand oriented while export equations are supply-oriented. Of the five equations for imports, three equations are behavioural and two are definitional identities. This model has studied the demand for consumer, intermediate and capital goods imports, while the demand for services has been treated as exogenous. The model covers the period $1959-60$ to $1978-89$. This study needs to be updated. Moreover, it is desirable to study both the demand and supply of imports. Sarmad and Mahmood (1985) have estimated import elasticities at a disaggregated level for the period 1969-80. They also obtained price and income elasticities for aggregate imports. They have reported mixed results for price and income elasticities. It is difficult to draw valid policy implications.

Though the assumption of infinite supply price elasticity is acceptable for the supply of imports to a single country [Goldstein and Khan (1978)]. It is, however, desirable to use a simultaneous equations model of import demand and supply, as it will help in policy formulation.

This study is different from the few studies [Khan (1974), Naqvi et al (1983), and Sarmad and Mahmood (1985)] on import behaviour of Pakistan in the following aspects. (a) To the best of our knowledge no other study except Khan (1974) has examined the demand and supply of imports in a simultaneous equation framework. The period of the Khan (1974) study was 1951-69. The Khan (1974) study needs to be updated because much has changed (geography as well as policies) after 1969 (b) This study uses a dummy variable, not done by other studies on the import behaviour of Pakistan, to see the impact of liberalisation efforts on imports since the beginning of the 1990s.

The purpose of the paper is to investigate the stated aspects regarding the import behaviour of Pakistan for the period 1960 - 1999. Section II gives the description of the model and data sources. Results and discussion are given in Section III and the conclusions are given in the final section. 


\section{Model and Data Sources}

The imports are a function of the real domestic income and the real price of imports. Similarly, supply of imports depends on world income, price of imports and the general price level. Therefore, in log-linear form, the following equations for import demand and supply are specified.

Import Demand Equations

$$
\begin{aligned}
& \operatorname{LnMd}=\beta_{0}+\beta_{1} \operatorname{LnPi}+\beta_{2} \operatorname{LnYpak} \\
& \operatorname{LnMd}=\beta_{0}+\beta_{1} \operatorname{LnPi}+\beta_{2} \operatorname{LnYpak}+\beta_{3} \text { Do }
\end{aligned}
$$

Where

$$
\begin{aligned}
& \mathrm{Ln}=\text { natural logarithm } \\
& \text { Md = Real value of imports demand } \\
& \text { Ypak }=\text { real GDP of Pakistan } \\
& \mathrm{PM}=\text { unit value of imports of Pakistan } \\
& \text { Pd }=\text { Wholesale Price index (WPI) of Pakistan } \\
& \mathrm{Pi}=(\mathrm{PM} / \mathrm{Pd})=\text { ratio of the unit value of imports }(\mathrm{PM}) \text { of Pakistan to } \\
& \text { WPI of Pakistan } \\
& \text { Do }=0 \text { for } 1959-60 \text { to } 1988-89 \text { (Pre-liberalisation) } \\
& =1 \text { for } 1989-90 \text { to } 1999 \text { (Post-liberalisation) }
\end{aligned}
$$

'Do' is the liberalisation dummy as Pakistan embarked on its trade liberalisation programme in the early 1990s. During the 1950s and 1960s most developing countries including Pakistan opted for vigorous industrialisation through Import Substitution (IS). In the following decades (1970s, 1980) a policy mix of export-promotion and import-substitution was pursued in Pakistan. During the 1990s import-liberalisation and exportpromotion policies have been followed in Pakistan [Pakistan Economic Survey (1991-92), p.xxxii]. Therefore, a study of the impact of liberalisation efforts on imports is desirable.

The expected signs of the coefficients in equations 1 and 2 are: $\beta_{1}<_{0}$, $\beta_{2}>_{0}$ and the sign of $\beta_{3}$ the coefficient of 'Do' is uncertain as it is difficult to say something with certainty about the positive or negative effects of liberalisation. 
112 The Lahore Journal of Economics, Vol.6, No.2

Import Supply Equations

$$
\begin{aligned}
& \mathrm{LnMs}=\gamma_{0}+\gamma_{1} \mathrm{LnPM}+\gamma_{2} \mathrm{LNPW}+\gamma_{3} \mathrm{LnZW} \\
& \mathrm{LNMs}=\gamma_{0}+\gamma_{1} \mathrm{LnPM}+\gamma_{2} \mathrm{LNPW}+\gamma_{3} \mathrm{LnZW}+\gamma_{4} \mathrm{Do}
\end{aligned}
$$

Where

$$
\begin{aligned}
& \text { Ms }=\text { Real value of imports supply } \\
& \text { ZW }=\text { World real income } \\
& \text { PW }=\text { Wholesale Price index of the world } \\
& \text { Do = as explained above in the import demand equation } 2 .
\end{aligned}
$$

The signs of coefficients in equation 3 and 4 are expected to be: $\gamma_{1}<_{0}$, $\gamma_{2}>_{0}$ and $\gamma_{3}>0$. The sign of $\gamma_{4}$ the coefficient of 'Do' is uncertain.

All the data on imports have been taken from the Pakistan Economic Survey (various issues). Real World Income data have been taken from World Tables. The data regarding world wholesale price Index (WPI) and unit value of imports in domestic currency have been taken from International Financial Statistics (IFS) yearbooks (various years). All the variables are in natural logarithm and are in constant $1989-90=100$ prices.

\section{Results and discussions}

Tables 1 and 2 give OLS and TSLS results about import demand and supply. The instruments list is lagged [GDP, imports, import prices, domestic prices, world wholesale prices, and world income]. Consumer and wholesale price indices of Pakistan, growth of world income, dummy, and world wholesale prices.

Traditional as well as dummy included forms of the import functions [Equations 1 and 2] show those variables have expected signs. The price coefficient is negative but not significant and the domestic income coefficient is positive and is significant in both equations. The liberalisation dummy coefficient is negative but not significant implying that trade liberalisation does not have a healthy impact on demand for imports, though it is not crucial.

Economic theory says that like consumption and saving, imports are also an increasing function of domestic income. Therefore, estimation results are in agreement with economic theory and so is the relative price variable. But the less significant nature of the price variable shows that the

demand for imports is inelastic because of the immense need of the diverse 
imports. Khan's (1974) study covering 15 countries including Pakistan for the period 1951-69 reported a significant price coefficient $(-0.779)$. Three factors are likely to have influenced Khan's estimate. First, his study covered a period when Pakistan's exchange rate was overvalued. Second, foreign aid financed imports. Third, a low inflation rate may be a very potential factor in making the price coefficient significant. During the 1970s and 1990s Pakistan had a very high inflation rate. Since in the import demand the import price is deflated by the domestic price index, a high index can make the ratio less significant thus domestic inflationary pressure appears to be the most potential factor in turning out a less significant price coefficient.

Sarmad and Mahmood [1985] got mixed results for certain sub-groups of imports for the period 1960-80. For many sub-groups, the price elasticities were significant, while they also had insignificant as well as positive values for some cases. The results of this study cannot be compared with those of Sarmad and Mahmood [1985] as their imports were disaggregated.

Table-1: Imports Demand

\begin{tabular}{ccccc}
\hline Variables & \multicolumn{2}{c}{ Equation-1 } & \multicolumn{2}{c}{ Equation-2 } \\
\hline \multirow{2}{*}{ Constant } & 1.38 & 1.41 & 1.13 & 1.12 \\
& $(0.65)$ & $(0.49)$ & $(0.46)$ & $(0.45)$ \\
Pi & -0.09 & -0.35 & -0.08 & -0.08 \\
& $(-0.68)$ & $(-1.19)$ & $(-0.59)$ & $(-0.60)$ \\
Ypak & 0.53 & 0.52 & 0.54 & 0.55 \\
& $(3.21)^{*}$ & $(2.41)^{*}$ & $(2.85)^{*}$ & $(2.34)^{*}$ \\
Do & - & - & -0.04 & -0.04 \\
& & & $(-0.65)$ & $(-0.65)$ \\
$\mathrm{R}^{2}$ & 0.87 & 0.86 & 0.86 & 0.86 \\
D.W. & 1.66 & 1.60 & 1.65 & 1.54 \\
\hline
\end{tabular}

Note: The number in parentheses in Tables 1 and 2 are t-statistics where ${ }^{*}$ stands for $5 \%$ and $* *$ for $10 \%$ levels of significance respectively in both Tables.

However, current domestic income is significant in both estimations. Equations 3 and 4 show inferior estimates for import supply in both OLS and TSLS. This finding indicates that the assumption of a very large or infinite import supply to an individual country appears to be acceptable. World income turns out to be the major determinant of import supply implying that good economic conditions in the world ensure greater supply of imports, and prices are less important. 
114 The Lahore Journal of Economics, Vol.6, No.2

Table-2: Imports Supply

\begin{tabular}{ccccc}
\hline Variables & \multicolumn{2}{c}{ Equation-3 } & \multicolumn{2}{c}{ Equation-4 } \\
\hline & OLS & TSLS & OLS & TSLS \\
\hline \multirow{2}{*}{ Constant } & -7.61 & -8.89 & -7.39 & -10.83 \\
& $(-0.65)$ & $(-0.35)$ & $(-0.58)$ & $(-0.63)$ \\
PM & -0.05 & -0.29 & -0.05 & -0.28 \\
& $(-0.58)$ & $(-0.68)$ & $(-0.57)$ & $(-0.91)$ \\
PW & 0.07 & 0.25 & 0.09 & 0.19 \\
& $(0.38)$ & $(0.87)$ & $(0.41)$ & $(0.62)$ \\
ZW & 0.96 & 1.05 & 0.94 & 1.18 \\
& $(1.31)$ & $(0.66)$ & $(1.27)$ & $(1.08)$ \\
Do & - & - & -0.03 & 0.11 \\
R & & & $(-0.42)$ & $(0.64)$ \\
D.W. & 0.87 & 0.86 & 0.87 & 0.85 \\
& 1.61 & 1.60 & 1.60 & 1.55 \\
\hline
\end{tabular}

\section{Conclusions}

Traditional as well as dummy included forms of the import functions show that variables have expected signs. The price coefficient is negative and not significant but the domestic income coefficient is positive and significant in both equations. Liberalisation does not have a positive impact on demand for imports, though it is not significant. Maintenance of real effective exchange rate under a liberal trade regime has increased the value of imports but not the volume of imports (Pakistan Economic Survey, 19992000).

Estimation results are in agreement with economic theory. But the nature of the price variable shows that the demand for imports is inelastic because of the huge need of diverse imports. The domestic inflationary pressure appears to be the most potential factor in turning out a less significant price coefficient.

On the basis of inferior estimates for import supply in both estimations, this study concludes that the assumption of a very large or infinite import supply to an individual country appears to be acceptable or as suggested by Haynes and Stone $(1983$ b) supply-price instead of imports quantity or value may be used as the dependent variable. 


\section{References}

Arize, A. 1986, "The Supply and Demand for Imports and Export in a Simultaneous Model”, Pakistan Economic and Social Review, Vol.24, No.2, pp. 57-76.

Godstein, M. and Mohsen S. Khan 1978, "The Supply and Demand for Exports: A Simultaneous Approach”, Review of Economics and Statistics, Vol.60, No.2, pp. 275-286.

Haynes, S. and J. Stone 1983a, "Secular and Cyclical Response of US Trade to Income: An Evaluation of Traditional Models”, Review of Economics and Statistics, Vo1.65, pp. 87-95.

Haynes, Sand and J. Stone, 1983b, "Specification of Supply Behaviour in International Trade”, Review of Economics and Statistics, Vol.65, pp. 626-631.

IMF, International Financial Statistics (Various issues).

Khan, Mohsin S. 1974, "Import and Export Demand in Developing Countries”, IMF Staff Papers, Vo1.21, pp. 678-693.

Khan, M.S. and K.Z. Ross 1977, "The Functional Form of the Aggregate Import Demand Equation" Journal of International Economics, Vol.7, pp. 149-160.

Leamer, Edward and R.M. Stern 1970, Quantitative International Economics, Boston, Allyn Bacon.

Murray, Tracy and P. Ginman 1976, "An Empirical Examination of the Traditional Aggregate Import Demand Model”, Review of Economics and Statistics, Vol.58, pp. 75-80.

Naqvi et al 1983, The PIDE Macro-Econometric Model of Pakistan's Economy, Islamabad, Pakistan Institute of Development Economics (PIDE).

Sarmad, K. 1989, "The Determinants of Import Demand in Pakistan", World Development, Vo1.17, No.10, pp. 1619-1625. 
116 The Lahore Journal of Economics, Vol.6, No.2

Sarmad, K. and Riaz Mahmood 1985, "Price and Income Elasticities of Consumer Goods Imports” Pakistan Development Review, Vo1.24, No.3\&4, pp. 453-461.

Pakistan, Government of Pakistan Economic Survey [various issues], Islamabad, Ministry of Finance, Economic Advisor Wing.

World Bank, World Tables (various issues). 